\title{
PERANAN GAYA KEPEMIMPINAN, MOTIVASI DAN DISIPLIN KERJA TERHADAP KINERJA KARYAWAN
}

Oleh : Unik Desthiani, S.Si, S,Psi, MM

Dosen Prodi Sekretari Universitas Pamulang

unikdesthiani@gmail.com

\begin{abstract}
Abstrak
Dalam sebuah perusahaan sumber daya manusia merupakan aset terpenting yang dapat menentukan kesuksesan sebuah perusahaan. Selain dari sumber daya lain seperti : bahan baku, peralatan, perlengkapan, produk dan lain-lain. Sumber daya manusia itu sendiri adalah individu yang bekerja sebagai penggerak suatu organisasi, baik itu dalam institusi maupun perusahaan yang memiliki fungsi sebagai aset sehingga harus dilatih dan dikembangkan kemampuannya.

Perbedaan antara sumber daya manusia dengan sumber daya lainnya adalah adanya cipta, rasa, dan karsa yang dimiliki oleh manusia dan tidak di miliki oleh sumber daya lainnya. Manusia mempunyai keinginan, kebutuhan dan penghargaan sehingga pengusaha atau pemimpin dalam suatu perusahaan harus memperhatikan apa yang menjadi keinginan, kebutuhan dan harapan dari sumber daya manusia selaku pekerja di perusahaannya. Apabila suatu perusahaan sudah memenuhi kebutuhan dan harapan pekerjanya maka pekerja akan dapat memberikan yang terbaik bagi perusahaan.

Penulisan ini dibuat dengan tujuan untuk mengetahui peranan gaya kepemimpinan, motivasi, dan disiplin kerja terhadap kinerja karyawan.
\end{abstract}

Kata Kunci: Gaya kepemimpinan, Motivasi, Disiplin Kerja dan Kinerja Karyawan

\section{PENDAHULUAN}

\section{A. Latar Belakang Masalah}

Dalam berbagai aspek kehidupan dan berorganisasi, faktor manusia merupakan faktor utama di setiap kegiatan yang ada di dalamnya. Organisasi merupakan kesatuan 
sosial yang dikoordinasikan secara sadar dengan sebuah batasan yang reaktif dapat diidentifikasikan, bekerja secara terus menerus untuk mencapai tujuan (Robbins, 2006). Semua tindakan yang diambil dalam setiap kegiatan diprakarsai dan ditentukan oleh manusia yang menjadi anggota perusahaan. Sumber daya manusia seperti : pemimpin dan karyawan yang memiliki potensi tinggi dan baik sangat dibutuhkan oleh perusahaan untuk dapat melaksanakan tugas, kewajiban dan wewenangnya dengan baik sesuai dengan rencana perusahaan agar dapat mencapai apa yang menjadi tujuan perusahaan.

Sumber daya manusia merupakan tokoh sentral dalam organisasi maupun perusahaan. Untuk menjamin bahwa aktivitas dan manajemen suatu perusahaan berjalan dengan baik, maka perusahaan harus mempunyai karyawan yang memiliki pengetahuan, kemampuan dan keterampilan yang baik serta memiliki keinginan untuk dapat mengelola perusahaan dengan optimal sehingga kinerja karyawan meningkat.

Menurut Budi Setiyawan dan Waridin (2006) kinerja karyawan merupakan hasil atau prestasi kerja karyawan yang dinilai dari segi kualitas maupun kuantitas berdasarkan standar kerja yang ditentukan oleh pihak organisasi. Kinerja yang baik adalah kinerja yang optimal, yaitu kinerja yang sesuai standar organisasi dan mendukung tercapainya tujuan organisasi. Organisasi yang baik adalah organisasi yang berusaha meningkatkan kemampuan sumber daya manusianya, karena hal tersebut merupakan faktor kunci untuk meningkatkan kinerja karyawan.

Peningkatan kinerja karyawan akan memberikan kesuksesan dan kemajuan bagi perusahaan tidak hanya dalam jangka waktu pendek tetapi bisa memberikan kesuksesan dan kemajuan dalam jangka waktu panjang sehingga perusahaan dapat bertahan dalam persaingan bisnis yang tidak stabil. Oleh karena itu upaya-upaya untuk meningkatkan kinerja karyawan merupakan tantangan yang besar dan sangat penting bagi manajemen karena hal tersebut merupakan penentu keberhasilan perusahaan dalam mencapai tujuan dan mempertahankan kelangsungan hidup perusahaan di mana tergantung pada kualitas kinerja sumber daya manusia yang ada di dalam perusahaan.

Semakin banyak karyawan yang mempunyai kinerja tinggi, maka produktivitas perusahaan secara keseluruhan akan meningkat sehingga perusahaan akan dapat bertahan dalam persaingan global. Karyawan dituntut untuk mampu menyelesaikan tugas dan tanggung jawabnya secara efektif dan efisien. Terdapat beberapa faktor negatif yang dapat menurunkan kinerja karyawan, diantaranya adalah menurunnya keinginan karyawan untuk mencapai prestasi kerja, kurangnya ketepatan waktu dalam menyelesaikan pekerjaan yang 
diberikan sehingga dianggap tidak mentaati perintah, pengaruh yang berasal dari lingkungan, misalnya: teman kerja yang menurun semangatnya, tidak adanya teladan yang bisa dijadikan contoh dalam pencapaian prestasi kerja yang baik. Semua itu merupakan sebab menurunnya kinerja karyawan dalam bekerja.

Faktor-faktor yang dapat digunakan untuk meningkatkan kinerja diantaranya adalah gaya kepemimpinan, motivasi dan disiplin kerja. Gaya kepemimpinan adalah sifat, kebiasaan, temperamen, watak dan kepribadian yang membedakan seorang pemimpin dalam berinteraksi dengan orang lain (Kartini Kartono, 2008). Seorang pemimpin harus menerapkan gaya kepemimpinan untuk mengelola bawahannya, karena seorang pemimpin akan sangat mempengaruhi keberhasilan organisasi dalam mencapai tujuannya (Waridin dan Bambang Guritno, 2005). Perusahaan menggunakan berbagai cara untuk memotivasi karyawannya, seperti : pemberian kompensasi, penghargaan dan hadiah sebagai balas jasa atas kinerja karyawan, diberlakukannya beberapa aturan dalam perusahaan untuk di taati oleh semua karyawan sebagai bentuk kedisiplinan, penghargaan perusahaan kepada karyawan yang bersifat non materiil sebagai salah satu pendorong motivasi yaitu : promosi jabatan, pemimpin yang mau mendengarkan pendapat atau ide yang diberikan oleh karyawan saat proses pengambilan keputusan.

Gaya kepemimpinan yang tepat akan menimbulkan motivasi seseorang untuk berprestasi. Sukses tidaknya karyawan dalam prestasi kerja dapat dipengaruhi oleh gaya kepemimpinan atasannya (Hardini, 2001 dalam Suranta, 2002). Suranta (2002) dan Tampubolon (2007) telah meneliti pengaruh gaya kepemimpinan terhadap kinerja, menyatakan bahwa gaya kepemimpinan mempunyai pengaruh yang signifikan terhadap kinerja karyawan. Motivasi adalah dorongan, upaya dan keinginan yang ada di dalam diri manusia yang mengaktifkan, memberi daya serta mengarahkan perilaku untuk melaksanakan tugas-tugas dengan baik dalam lingkup pekerjaannya (Hakim, 2006). Sedangkan Robbins (2006) mendefinisikan motivasi sebagai proses yang ikut menentukan intensitas, arah, dan ketekunan individu dalam usaha mencapai sasaran.

Motivasi sebagai proses yang bermula dari kekuatan dalam hal fisiologis dan psikologis atau kebutuhan yang mengakibatkan perilaku atau dorongan yang ditujukan pada sebuah tujuan atau insentif (Moekijat, 2001 dalam Hakim, 2006). Beberapa peneliti telah menguji hubungan antara motivasi dengan kinerja karyawan, antara lain Suharto dan Cahyono (2005), Hakim (2006). Pengaruh motivasi kerja terhadap kinerja menunjukan 
hasil yang sama bahwa hubungan antara motivasi dengan kinerja karyawan menunjukan hubungan positif dan signifikan.

Pendapat Budi Setiyawan dan Waridin (2006), disiplin sebagai keadaan ideal dalam mendukung pelaksanaan tugas sesuai aturan dalam rangka mendukung optimalisasi kerja. Salah satu syarat agar disiplin dapat ditumbuhkan dalam lingkungan kerja ialah, adanya pembagian kerja yang tuntas sampai kepada pegawai atau petugas yang paling bawah, sehingga setiap orang tahu dengan sadar apa tugasnya, bagaimana melakukannya, kapan pekerjaan dimulai dan selesai, seperti apa hasil kerja yang disyaratkan, dan kepada siapa mempertanggung jawabkan hasil pekerjaan itu (Budi Setiyawan dan Waridin, 2006). Untuk itu disiplin harus ditumbuh kembangkan agar tumbuh pula ketertiban dan efisiensi. Tanpa adanya disiplin tidak akan mungkin dapat diwujudkan adanya sosok pemimpin atau karyawan ideal sebagaimana yang diharapkan oleh perusahaan. Menurut Budi Setiyawan dan Waridin (2006), dan Aritonang (2005) disiplin kerja karyawan bagian dari faktor kinerja. Hasil penelitiannya menunjukan bahwa disiplin kerja memiliki pengaruh positif terhadap kinerja kerja karyawan.

Berdasarkan latar belakang yang ada, penulis bermaksud untuk menguraikan lebih lanjut mengenai "Peranan Gaya Kepemimpinan, Motivasi, dan Disiplin Kerja terhadap Kinerja Karyawan”.

\section{B. Identifikasi Masalah}

Berdasarkan latar belakang tersebut di atas, maka penulis mengidentifikasikan masalah sebagai berikut :

1. Penerapan gaya kepemimpinan terhadap tinggi rendahnya kinerja karyawan.

2. Besar kecilnya motivasi yang dimiliki karyawan terhadap kinerja karyawan.

3. Sikap disiplin kerja yang diterapkan terhadap kinerja kerja karyawan yang dihasilkan.

\section{A. Perumusan Masalah}

Berdasarkan identifikasi masalah di atas, maka penulis merumuskan masalah sebagai berikut :

1. Bagaimana peranan gaya kepemimpinan terhadap kinerja karyawan?

2. Bagaimana peranan motivasi terhadap kinerja karyawan?

3. Bagaiman peranan disiplin kerja terhadap kinerja karyawan? 


\section{PEMBAHASAN}

\section{A. Gaya Kepemimpinan}

Kepemimpinan merupakan hal terpenting dalam suatu perusahaan, karena seorang pemimpin harus bisa mempengaruhi semua orang yang menjadi bawahannya untuk bekerja sama agar dapat mencapai tujuan perusahaan. Dalam upaya untuk mempengaruhi orang lain, pemimpin perlu menerapkan gaya kepemimpinan yang sesuai dengan kondisi dan kebutuhan. Gaya kepemimpinan adalah pola menyeluruh dari tindakan seorang pemimpin, yang tampak dan yang tidak tampak oleh bawahannya. James et. al. (1996) mengatakan bahwa gaya kepemimpinan adalah berbagai pola tingkah laku yang disukai oleh pemimpin dalam proses mengarahkan dan mempengaruhi pekerja. Gaya kepemimpinan adalah erilaku dan strategi, sebagai hasil kombinasi dari falsafah, ketrampilan, sifat, sikap yang sering diterapkan seorang pemimpin ketika ia mencoba mempengaruhi kinerja bawahannya (Tampubolon, 2007).

Berdasarkan definisi gaya kepemimpinan diatas dapat disimpulkan bahwa gaya kepemimpinan adalah kemampuan seseorang dalam mengarahkan, mempengaruhi, mendorong dan mengendalikan orang lain atau bawahan untuk bisa melakukan sesuatu pekerjaan atas kesadarannya dan sukarela dalam mencapai suatu tujuan tertentu.

Terdapat lima gaya kepemimpinan yang disesuaikan dengan situasi menurut Siagian (2002), yaitu:

1. Tipe pemimpin yang otokratik

Seorang pemimpin yang otokratik ialah seorang pemimpin yang:

a. Menganggap organisasi sebagai milik pribadi.

b. Mengidentikan tujuan pribadi dengan tujuan organisasi.

c. Menganggap bahwa karyawan sebagai alat semata-mata.

d. Tidak mau menerima kritik, saran dan pendapat.

e. Terlalu tergantung pada kekuasaan formalnya.

f. Pendekatan terhadap karyawan mengandung unsur paksaan

2. Tipe pemimpin yang militeristik

Perlu diperhatikan terlebih dahulu bahwa yang dimaksud seorang pemimpin tipe militeristik berbeda dengan seorang pemimpin modern. Seorang pemimpin yang bertipe militeristik ialah seorang pemimpin yang memiliki sifat-sifat: 

a. Dalam menggerakan bawahannya sistem perintah yang sering dipergunakan.
b. Dalam menggerakan bawahannya senang bergantung pada pangkat dan jabatan.
c. Senang kepada formalitas yang berlebih-lebihan.
d. Menuntut disiplin yang tinggi dan kaku dari bawahannya.

3. Tipe pemimpin yang paternalistik
a. Menganggap bahwa sebagai manusia yang tidak dewasa.
b. Bersikap terlalu melindungi.
c. Jarang memberikan kesempatan kepada bawahannya untuk mengambil
d. keputusan.
e. Jarang memberikan kesempatan kepada bawahan untuk mengambil inisiatif.
f. Jarang memberikan kesempatan kepada bawahan untuk mengembangkan daya kreasi dan fantasi.
g. Sering bersikap mau tahu.

4. Tipe pemimpin yang kharismatik

Harus diakui bahwa untuk keadaan tentang seorang pemimpin yang demikian sangat diperlukan akan tetapi sifatnya yang negatif mengalahkan sifatnya yang positif.

5. Tipe pemimpin yang demokratik

Pengetahuan tentang kepemimpinan telah membuktikan bahwa tipe pemimpin yang demokratislah yang paling tepat untuk organisasi modern karena:

1. Ia senang menerima saran, pendapat dan bahkan kritikan dari bawahan.

2. Selalu berusaha mengutamakan kerjasama teamwork dalam usaha mencapai tujuan.

3. Selalu berusaha menjadikan bawahan lebih sukses darinya.

4. Selalu berusaha mengembangkan kapasitas diri pribadinya sebagai

5. pemimpin.

\section{B. Motivasi}

Motivasi dapat diartikan sebagai dorongan internal dan eksternal dalam diri seseorang yang diindikasikan dengan adanya hasrat dan minat, dorongan dan kebutuhan, harapan dan cita-cita, penghargaan dan penghormatan (Uno, 2007). Menurut Malthis (2001) 
motivasi merupakan hasrat didalam diri seseorang yang menyebabkan orang tersebut melakukan tindakan. Sedangkan Rivai (2004) berpendapat bahwa motivasi adalah serangkaian sikap dan nilai-nilai yang mempengaruhi individu untuk mencapai hal yang spesifik sesuai dengan tujuan individu.

Motivasi adalah kesediaan melakukan usaha tingkat tinggi guna mencapai sasaran organisasi yang dikondisikan oleh kemampuan usaha tersebut memuaskan kebutuhan sejumlah individu (Robins dan Mary, 2005). Motivasi merupakan faktor psikologis yang menunjukan minat individu terhadap pekerjaan, rasa puas dan ikut bertanggung jawab terhadap aktivitas atau pekerjaan yang dilakukan (Masrukhin dan Waridin, 2004). Sedangkan Hasibuan (2004) berpendapat bahwa motivasi adalah hal yang menyebabkan, menyalurkan dan mendukung perilaku manusia, supaya mau bekerja giat dan antusias mencapai hasil yang optimal.

Berdasarkan beberapa pengertian yang telah disampaikan diatas dapat disimpulkan bahwa motivasi adalah dorongan kehendak yang menyebabkan seseorang melakukan suatu perbuatan untuk mencapai tujuan. Seorang pemimpin perlu memahami setiap perilaku para bawahannya agar dapat mempengaruhi atau mengajak karyawan bekerja sama melaksanakan pekerjaan sesuai standar yang sudah di tetapkan perusahaan agar dapat mencapai tujuan perusahaan. Siagian (2002) mengemukakan bahwa dalam kehidupan berorganisasi, termasuk kehidupan berkarya dalam organisasi bisnis, aspek motivasi kerja mutlak mendapat perhatian serius dari para manajer karena 4 (empat) pertimbangan utama yaitu:

1. Filsafat hidup manusia berkisar pada prinsip "quit pro quo", yang dalam bahasa awam dicerminkan oleh pepatah yang mengatakan "ada ubi ada talas, ada budi ada balas".

2. Dinamika kebutuhan manusia sangat kompleks dan tidak hanya bersifat materi, akan tetapi juga bersifat psikologis.

3. Tidak ada titik jenuh dalam pemuasan kebutuhan manusia.

4. Perbedaan karakteristik individu dalam organisasi atau perusahaan, mengakibatkan tidak adanya satupun teknik motivasi yang sama efektifnya untuk semua orang dalam organisasi juga untuk seseorang pada waktu dan kondisi yang berbeda-beda.

Menurut Siagian (2002) ada enam teknik aplikasi teori motivasi, yaitu:

1. Manajemen berdasarkan sasaran atau management by objectives (MBO). 
2. Program penghargaan karyawan.

3. Program ketertiban karyawan.

4. Program imbalan bervariasi.

5. Rencana pemberian imbalan berdasarkan keterampilan.

6. Manfaat yang fleksibel.

Menurut Rivai (2004) terdapat beberapa perilaku yang dapat memotivasi karyawan:

1. Cara berinteraksi.

2. Menjadi pendengar aktif.

3. Penyusunan tujuan yang menantang.

4. Pendekatan penyelesaian masalah dan tujuan yang berfokus pada perilaku bukan pada pribadi.

5. Informasi yang menggunakan teknik penguatan.

\section{Disiplin Kerja}

Secara etimologi disiplin berasal dari bahasa latin "disipel” yang berarti pengikut. Seiring dengan perkembangan jaman, kata tersebut mengalami perubahan menjadi "discipline" yang artinya kepatuhan atau yang menyangkut tata tertib. Disiplin kerja adalah suatu alat yang digunakan para manajer untuk berkomunikasi dengan karyawan agar mereka bersedia untuk mengubah suatu perilaku serta sebagai suatu upaya untuk meningkatkan kesadaran dan kesediaan seseorang menaati semua peraturan perusahaan dan norma-norma sosial yang berlaku (Rivai, 2004). Hasibuan (2004) berpendapat bahwa kedisiplinan adalah kesadaran dan kesediaan seseorang menaati semua peraturan perusahaan dan norma-norma sosial yang berlaku.

Berdasarkan pengertian diatas dapat disimpulkan bahwa disiplin kerja adalah suatu sikap menghormati, menghargai, patuh dan taat terhadap peraturan-peraturan yang berlaku, baik yang tertulis maupun tidak tertulis serta sanggup menjalankannya dan tidak mengelak menerima sanksi-sanksinya apabila ia melanggar tugas dan wewenang yang diberikan kepadanya. 
Budi Setiyawan dan Waridin (2006) dalam Mohammad (2005), menyatakan bahwa ada 5 (lima) faktor dalam penilaian disiplin kerja terhadap pemberian layanan pada masyarakat, yaitu:

1. Kualitas kedisiplinan kerja, meliputi datang dan pulang yang tepat waktu. Pemanfaatan waktu untuk pelaksanaan tugas dan kemampuan mengembangkan potensi diri berdasarkan motivasi yang positif.

2. Kuantitas pekerjaan meliputi volume keluaran dan kontribusi.

3. Kompensasi yang diperlukan meliputi : saran, arahan atau perbaikan.

4. Lokasi tempat kerja atau tempat tinggal.

5. Konservasi meliputi penghormatan terhadap aturan dengan keberanian untuk selalu melakukan pencegahan terjadinya tindakan yang bertentangan dengan aturan.

Terdapat empat perspektif daftar yang menyangkut disiplin kerja menurut Rivai (2004):

1. Disiplin retributive (retributive discipline) yaitu berusaha menghukum orang yang berbuat salah.

2. Disiplin korektif (corrective discipline) yaitu berusaha membantu karyawan mengkoreksi perilakunya yang tidak tepat.

3. Perspektif hak-hak individu (individual right perspective) yaitu berusaha melindungi hak-hak dasar individu selama tindakan-tindakan disipliner.

4. Perspektif utilitarian (utilitarian perspective) yaitu berfokus kepada penggunaan disiplin hanya pada saat konsekuensi-konsekuensi tindakan disiplin melebihi dampakdampak negatifnya.

Rivai (2004) juga menyebutkan ada tiga konsep dalam pelaksanaan tindakan disipliner, yaitu:

1. Aturan tungku panas yaitu pendekatan untuk melaksanakan tindakan disipliner.

2. Tindakan disiplin progresif yaitu untuk memastikan bahwa terdapat hukum minimal yang tepat terhadap setiap pelanggaran.

3. Tindakan disiplin positif yaitu dalam banyak situasi, hukuman tindakan memotivasi karyawan mengubah suatu perilaku. 


\section{B. Kinerja Karyawan}

Kinerja berasal dari kata job performance atau actual performance yang berarti prestasi kerja atau prestasi sesungguhnya yang dicapai oleh seseorang. Pengertian kinerja (prestasi kerja) adalah hasil kerja secara kualitas dan kuantitas yang dicapai oleh seorang karyawan dalam melaksanakan fungsinya sesuai dengan tanggung jawab yang diberikan kepadanya. Menurut (Nurlaila, 2010) performance atau kinerja merupakan hasil atau keluaran dari suatu proses. Menurut pendekatan perilaku dalam manajemen, kinerja adalah kuantitas atau kualitas sesuatu yang dihasilkan atau jasa yang diberikan oleh seseorang yang melakukan pekerjaan (Luthans, 2005).

Kinerja merupakan perilaku organisasi yang secara langsung berhubungan dengan produksi barang atau penyampaian jasa. Informasi tentang kinerja organisasi merupakan suatu hal yang sangat penting digunakan untuk mengevaluasi apakah proses kinerja yang dilakukan organisasi selama ini sudah sejalan dengan tujuan yang diharapkan atau belum. Akan tetapi dalam kenyataannya banyak organisasi yang justru kurang atau bahkan tidak mempunyai informasi tentang kinerja dalam organisasinya. Kinerja sebagai hasil-hasil fungsi pekerjaan atau kegiatan seseorang atau kelompok dalam suatu organisasi yang dipengaruhi oleh berbagai faktor untuk mencapai tujuan organisasi dalam periode waktu tertentu (Tika, 2006). Sedangkan menurut Rivai dan Basri (2005) kinerja adalah kesediaan seseorang atau kelompok orang untuk melakukan sesuatu kegiatan dan menyempurnakannya sesuai dengan tanggung jawab dengan hasil seperti yang diharapkan.

Menurut Bambang Guritno dan Waridin (2005) kinerja merupakan perbandingan hasil kerja yang dicapai oleh karyawan dengan standar yang telah ditentukan. Sedangkan menurut Hakim (2006) mendefinisikan kinerja sebagai hasil kerja yang dicapai oleh individu yang disesuaikan dengan peran atau tugas individu tersebut dalam suatu perusahaan pada suatu periode waktu tertentu, yang dihubungkan dengan suatu ukuran nilai atau standar tertentu dari perusahaan dimana individu tersebut bekerja. Kinerja merupakan perbandingan hasil kerja yang dicapai oleh pegawai dengan standar yang telah ditentukan (Masrukhin dan Waridin, 2004).

Berdasarkan pengertian kinerja dari beberapa pendapat para ahli diatas, kinerja merupakan perbandingan hasil kerja yang dicapai oleh karyawan dengan standar yang telah ditentukan. Kinerja juga berarti hasil yang dicapai oleh seseorang, baik kuantitas maupun kualitas dalam suatu organisasi sesuai dengan tanggung jawab yang dberikan kepadanya. 
Tika (2006) mengemukakan bahwa ada 4 (empat) unsur-unsur yang terdapat dalam kinerja yaitu:

1. Hasil-hasil fungsi pekerjaan.

2. Faktor-faktor yang berpengaruh terhadap prestasi karyawan.

3. Pencapaian tujuan organisasi.

4. Periode waktu tertentu.

Menurut Rivai dan Basri (2005) kinerja pada dasarnya ditentukan oleh tiga (3) hal, yaitu sebagai berikut:

1. Kemampuan.

2. Keinginan.

3. Lingkungan.

Rivai dan Basri (2005) juga menyebutkan empat (4 )aspek kinerja, yaitu sebagai berikut:

1. Kemampuan.

2. Penerimaan tujuan perusahaan.

3. Tingkat tujuan yang dicapai.

4. Interaksi antara tujuan dan kemampuan para karyawan dalam perusahaan

Sedangkan tujuan kinerja menurut Rivai dan Basri (2005) adalah sebagai berikut:

1. Kemahiran dari kemampuan tugas baru diperuntukan untuk perbaikan hasil kinerja dan kegiatannya.

2. Kemahiran dari pengetahuan baru dimana akan membantu karyawan dengan pemecahan masalah yang kompleks atas aktivitas membuat keputusan pada tugas.

3. Kemahiran atau perbaikan pada sikap terhadap teman kerjanya dengan satu aktivitas kinerja.

4. Target aktivitas perbaikan kinerja.

5. Perbaikan dalam kualitas atau produksi.

6. Perbaikan dalam waktu atau pengiriman.

Yuwalliatin (2006) mengatakan bahwa kinerja diukur dengan instrumen yang dikembangkan dalam studi yang tergabung dalam ukuran kinerja secara umum kemudian diterjemahkan kedalam penilaian perilaku secara mendasar, meliputi: 
1. Kuantitas kerja

2. Kualitas kerja

3. Pengetahuan tentang pekerjaan

4. Pendapat atau pernyataan yang disampaikan

5. Perencanaan kegiatan

\section{Pembahasan peran gaya kepemimpinan terhadap kinerja karyawan}

Gaya kepemimpinan merupakan pola perilaku dan strategi yang disukai dan sering di terapkan seorang pemimpin. Gaya kepemimpinan antara pemimpin yang satu dengan lainnya berbeda karena watak, karakter juga menentukan dan mempengaruhi gaya kepemimpinan seorang pemimpin. Di dalam suatu perusahaan selain tujuan perusahaan terdapat juga tujuan-tujuan individu dari para karyawan, seperti : kenaikan gaji, kenaikan pangkat, dan lain-lain. Pemimpin yang baik harus dapat memperhatikan apa yang menjadi harapan dan tujuan karyawan yang di pimpinnya,

Gaya kepemimpinan pada dasarnya menekankan untuk menghargai tujuan individu sehingga nantinya para individu akan memiliki keyakinan bahwa kinerja aktual akan melampaui harapan kinerja mereka. Dengan menghargai dan memahami tujuan-tujuan individu, akan lebih mudah bagi seorang pemimpin untuk mendorong karyawan agar mampu memberikan kinerja yang baik bagi perusahaan sehingga tujuan individu tercapai dan tujuan perusahaan juga tercapai.

Seorang pemimpin harus menerapkan gaya kepemimpinan untuk mengelola bawahannya, karena seorang pemimpin akan sangat mempengaruhi keberhasilan organisasi dalam mencapai tujuannya (Waridin dan Bambang Guritno, 2005). Jika seorang pemimpin menggunakan gaya kepemimpinan yang tepat dan membuat karyawan atau bawahannya merasa nyaman, maka akan mudah bagi pemimpin tersebut untuk mempengaruhi karyawannya agar mau bekerja secara optimal untuk mencapai tujuan perusahaan. Suranta (2002) dan Tampubolon (2007) menyatakan bahwa faktor kepemimpinan juga berpengaruh terhadap kinerja karyawan. Berdasarkan penjelasan di atas dan pendapat para ahli tersebut dapat disimpulkan bahwa peranan gaya kepemimpinan sangat berpengaruh terhadap kinerja karyawan. 


\section{Pembahasan peran motivasi terhadap kinerja karyawan}

Pengelolaan sumber daya harus dilakukan secara akurat terutama penetapan dan penggunaannya demi mempertahankan eksistensi kelangsungan hidup perusahaan. Sumber daya manusia harus ditempatkan pada suatu jabatan yang tepat agar kelancaran dan kualitas pekerjaan dapat diwujudkan.

Sumber daya manusia termasuk salah satu sumber daya yang paling penting dan dominan dalam mengantar perusahaan mencapai tujuan. Tersedianya modal, peralatan (mesin) dan komponen-komponen lainnya tanpa didukung oleh kualitas sumber daya manusia yang memadai, maka sulit memperoleh laba yang besar. Oleh karena itu, efektif atau tidaknya penggunaan komponen-komponen yang dimiliki perusahaan sangat bergantung pada kualitas sumber daya manusia yang dimiliki.

Kualitas sumber daya manusia dapat diperoleh melalui beberapa upaya, diantaranya: pemberian Pendidikan dan pelatihan, pembinaan disiplin, pemberian sanksi yang tegas dan penilaian prestasi kerja. Dengan adanya Pendidikan dan pelatihan, karyawan akan memperoleh tambahan pengetahuan dan keterampilan, sehingga karyawan dapat meningkatkan kualitas kerjanya dari sebelumnya. Peningkatan kualitas sumber daya manusia tidak akan ada artinya tanpa dilandasi dengan motivasi yang tinggi dan kemauan yang besar sehingga mendorong dirinya lebih maju dan berkembang sesuai dengan kemampuannya.

Indikator utama yang harus dimiliki seseorang dalam mencapai tujuan tertentu adalah bagaiman menumbuhkan motivasi tersebut, mereka dapat berusaha untuk memenuhi kebutuhan dan keinginannya melalui usaha dan kerja keras. Motivasi sangat berhubungan dengan faktor psikologis seseorang yang mencerminkan hubungan atau interaksi antara sikap, kebutuhan dan kepuasan yang terjadi pada diri manusia sehingga dapat mempengaruhi kinerjanya. Tanpa motivasi, orang tidak akan dapat melakukan sesuatu. Motivasi yang timbul dari dalam diri manusia yang disebut intrinsik dan sumber dari luar diri manusia yang disebut ekstrinsik. Seorang pemimpinlah yang bertugas untuk menumbuhkan motivasi kepada karyawan, dengan memberikan kepuasan kepada karyawan seperti : penghargaan atas prestasi (bonus, insentif), kenaikan jabatan, dan lain-lain akan dapat memenuhi kebutuhan karyawan sehingga karyawan merasa diperhatikan, dengan begitu akan menumbuhkan motivasi pada diri karyawan untuk dapat memiliki kinerja yang 
baik. Berdasarkan penjelasan tersebut di atas, dapat disimpulkan bahwa peranan motivasi terhadap kinerja sangat besar.

\section{B. Pembahasan displin kerja terhadap kinerja karyawan}

Salah satu upaya untuk memperoleh sumber daya manusia yang berkualitas adalah melalui pembinaan disiplin. Disiplin akan mendorong karyawan untuk konsisten terhadap waktu kerja, seperti : penggunaan jam kerja dan tingkat penyelesaian pekerjaan, sehingga pekerjaan dapat diselesaikan dengan tepat waktu. Hal ini tentunya akan berpengaruh terhadap aktivitas atau kegiatan suatu perusahaan, jika para karyawan disiplin dalam pelaksanaan tugas maka segala sesuatu akan berjalan secara efektif dan efisien.

Menurut Moenir (2004) disiplin kerja pada dasarnya selalu diharapkan menjadi ciri setiap sumber daya manusia dalam organisasi karena dengan kedisiplinan, organisasi akan berjalan dengan baik dan bisa mencapai tujuannya dengan baik pula. Setiap karyawan harus memiliki disiplin kerja didalam perusahaan, seperti : mematuhi peraturan tertulis maupun tidak tertulis yang telah di tetapkan oleh perusahaan karena hal tersebut dapat menciptakan lingkungan kerja yang kondusif dan harmonis sehingga akan memberikan dampak yang positif terhadap kinerja karyawannya.

Berdasarkan penjelasan diatas dapat disimpulkan bahwa disiplin kerja merupakan faktor penting dalam meningkatkan kinerja karyawan. Dengan adanya disiplin kerja yang baik dari karyawan seperti : datang tepat waktu, melaksanakan pekerjaan sesuai dengan apa yang telah ditetapkan oleh perusahaan, mentaati peraturan perusahaan maka akan dapat meningkatkan kinerja dari karyawan sehingga target perusahaan akan tercapai.

\section{KESIMPULAN DAN SARAN}

\section{A. Kesimpulan}

Dalam suatu perusahaan sumber daya manusia merupakan hal yang terpenting dan berpengaruh terhadap kesuksesan suatu perusahaan. Sumber daya manusia merupakan penggerak seluruh kegiatan dan aktivitas perusahaan agar mencapai tujuan yang telah direncanakan. Tetapi jika dibandingkan dengan sumber daya lainnya, sumber daya manusia merupakan salah satu permasalahan yang kompleks di suatu perusahaan, karena manusia 
berbeda dengan sumber daya lainnya, manusia memiliki cipta, rasa, kebutuhan, keinginan, penghargaan, dan lain-lain.

Kualitas dan kinerja karyawan di suatu perusahaan, di pengaruhi oleh beberapa hal diantaranya gaya kepemimpinan atasan, motivasi karyawan itu sendiri baik yang bersifat intrinsik atau ekstrinsik, dan sikap disiplin kerja dari karyawan tersebut. Berdasarkan pembahasan dan penjelasan di atas dapat disimpulkan bahwa peranan gaya kepemimpinan, motivasi dan displin kerja sangat terkait secara signifikan terhadap kinerja karyawan di suatu perusahaan.

\section{B. Saran}

Suatu perusahaan apabila ingin mencapai tujuan secara optimal dan bertahan di dalam persaingan bisnis yang ketat harus memperhatikan aspek terpenting di dalam perusahaan, yaitu sumber daya manusia. Perusahaan harus selalu meningkatkan kualitas sumber daya manusia yang dimiliki agar karyawan atau sumber daya manusia tersebut dapat memberikan kinerja yang terbaik. Kinerja yang terbaik dapat diwujudkan dengan adanya kerjasama antara perusahaan dan karyawan itu sendiri, upaya untuk menghasilkan kinerja yang terbaik di antaranya adalah :

1. Penerapan gaya kepemimpinan yang sesuai dengan kondisi dan situasi dimana gaya kepemimpinan yang diterapkan melibatkan karyawan dalam pengambilan keputusan, sehingga karyawan merasa dihargai oleh pemimpin dan perusahaan.

2. Pemberian motivasi terhadap setiap karyawan yang dilakukan oleh pemimpin, pemberian motivasi diantaranya berupa : komunikasi yang baik antara pemimpin dan karyawan, lingkungan kerja yang kondusif, pemberian bonus dan insentif, promosi jabatan, kenaikan gaji, dan lain-lain.

3. Penerapan disiplin kerja di lingkungan perusahaan harus dilakukan oleh seluruh unsur yang terdapat di dalam perusahaan, dari mulai pemimpin sampai dengan karyawan tingkat bawah, seperti : satpam dan OB. Pemimpin harus melaksanakan kedisiplinan kerja agar bisa menjadi teladan bagi semua karyawan. Penerapan disiplin kerja akan membuat semua aktivitas dan kegiatan di perusahaan berjalan secara efektif dan efisien. 


\section{DAFTAR PUSTAKA}

Handoko, T. Hani, 2003, Manajemen Edisi 2, BPFE, Yogyakarta.

Hasibuan, Malayu, 2004, Manajemen Sumber Daya Manusia, PT Bumi Aksara, Jakarta.

Malthis, R.L dan Jackson, 2001, Manajemen Sumber Daya Manusia, Salemba Empat, Jakarta.

Masrukhin dan Waridin, 2004, Pengaruh Motivasi Kerja, Kepuasan Kerja, Budaya Organisasi Dan Kepemimpinan Terhadap Kinerja Pegawai, EKOBIS. Vol 7. No 2. Hal: 197-209.

Robbins, Stephen. P, 2006, Perilaku organisasi, Edisi Bahasa Indonesia, PT Indeks Kelompok GRAMEDIA, Jakarta.

Robbins, Stephen. P. dan Mary Coulter, 2005, Manajemen, PT INDEKS Kelompok Gramedia, Jakarta.

Rivai, Veithzal, 2004, Manajemen Sumber Daya Manusia Untuk Perusahaan. PT RAJAGRAFINDO PERSADA, Jakarta

Rivai, Veithzal dan Basri, 2005, Performance Appraisal: Sistem Yang Tepat Untuk Menilai Kinerja Karyawan Dan Meningkatkan Daya Saing Perusahaan, PT RAJAGRAFINDO PERSADA, Jakarta.

Siagian, Sondong. P, 2002, Kiat Meningkatkan Produktivitas Kerja, PT Rineka Cipta, Jakarta.

Tika, P, 2006, Budaya Organisasi Dan Peningkatan Kinerja Perusahaan, PT Bumi Aksara, Jakarta. 